\title{
The Discretion of the Regional Head District in the Implementation of Regional Autonomy in Indonesia
}

\author{
Ishviati Joenaini Koenti ${ }^{1}$, Francisca Romana Harjiyatni ${ }^{2}$ \\ \{kunti.ishvi@gmail.com ${ }^{1}$, sisca.rh@gmail.com $\left.{ }^{2}\right\}$ \\ ${ }^{1,2}$ Faculty of Law, Janabadra University 55231, Indonesia
}

\begin{abstract}
The principle of regional autonomy applied in Indonesia gives the local authorities the authority to regulate and manage the interests of local communities according to their initiative based on the aspirations of the people. The authority of regional governments to regulate and manage the interests of the local community also results in the use of discretionary acts by officials in the area to solve problems that suddenly arise. However, there is no rule, given the choice or rules are not yet clear. Discretion has become a necessity. The problems under the research are: 1) why the application of discretion necessary in the administration of the local government is?; and 2) and does the integrity of regional heads affect the precise application of discretion? By using responsive legal theory as an analytical tool, it examines the implications of local government law and government administration law governing discretion. From the results of research in some areas, Bantul Regency, Yogyakarta City, Surakarta City, Temanggung Regency, and Bantaeng Regency, it is found that discretionary authority is given to the region, either explicitly or implicitly formulated. Given the application of discretion to the Regional Government is the freedom to act from the Head of Region, the responsive law reinforces the discretion for social welfare purposes. Openness and integrity are mutually reinforcing. If the regional head can understand the law as integrative law that contains the value (Pancasila), then the right products and actions resulting from the application of discretion will achieve the goal. However, with the enactment of Law No. 23 of 2014 on Regional Government and Law No. 30 on Government Administration, Discretion is arranged in great detail, so discretion loses the "spirit." Detailed restrictions on discretionary use are the characteristic of autonomous law. The conclusions from the results of the study indicate that Indonesia has not fully implemented responsive law. Supervision over the application of discretion has not been emphasized on the achievement of objectives by involving community participation.
\end{abstract}

Keyword:discretion, regional autonomy

\section{Introduction}

Decentralization is a means to give authority to regions to be able to initiate in their local government. Autonomy is an order of state (staatsrechtelijk) which contains the meaning of freedom (zelfstandigheid) which can be accounted for not independence (onafhankelijkid)[1]. There are two elements contained in autonomy: (1) assigning tasks in the sense of some work to be accomplished by the region, (2) giving authority to think and self-determining the way of completion of the work [1]. Juridically, the concept of the autonomous region contains elements of authority to organize and manage. The authority to regulate and manage is the substance of regional autonomy.

Local authority includes authority in all areas of government except for authority in the field of foreign policy, security, judiciary, monetary and fiscal defense, religion, and other 
areas of authority which will be further regulated by government regulations. Such authority includes planning, implementation, supervision, control, and evaluation. Broad, real, and responsible autonomy by the mandate of the 1945 Constitution of the State of the Republic of Indonesia has become a significant challenge for local governments to reform themselves to be more responsive, efficient but effective in carrying out governance and development function[2]. The implementation of local government is directed to accelerate the realization of community welfare through the improvement of service, empowerment, community participation, and enhancement of regional competitiveness by taking into account the principles of democracy, equity, justice, and uniqueness of a region in the system of the Unitary State of the Republic of Indonesia. The authority of the regional administration resulted in the use of discretionary acts by officials in the regions to address the suddenly arising problems but without rules or the rules are not yet clear with discretion.

\section{Methodology}

Based on the background, researched the implementation of discretion in 5 areas: Bantul District, Yogyakarta City, Solo City, Bantaeng Regency, and Temanggung Regency, the research problems formulated is: Why is the application of discretion necessary in the implementation of local government and how is it implemented?

This type of research is descriptive qualitative research, by using the approach of sociological, legal research (micro socio-legal research), which is a constructivist approach because it takes the subjective thinking of the regional head in the implementation of the discretion. The constructivist approach used by placing the existing law is consensus, agreement, or consultative relative among various understanding, opinion, or opinion about the problem faced, according to the context of space and time.

\section{Findings}

The concept of the State Welfare or the modern legal state provides the obligation of state administration to take an active role in all aspects of the life of its people. By making changes to the governance that provides more significant role and space to local institutions and nongovernmental organizations, governmental activities are not only more participatory but also more responsive and accountable to the public interest [3]. The concept of good governance has become a political will in various laws and regulations in the Unitary State of the Republic of Indonesia [4].

The importance of good local governance in overcoming the problems of the region is laid on two things. First, internal balance, which regulates the relationship between the organs of local government and society, especially those that include matters relating to the institutional and mechanisms of local governance. Second, external balances that emphasize the local government as a social entity residing amid a society that should pay attention to the relationship between local government and all regional stakeholders as a manifestation of the fulfillment of local government responsibilities. Given the discretionary authority exists because of legitimate power, the integrity of the officials, including ethics and morals becomes essential.

Government officials must achieve the goal because for that authority is given. The official is a functionary of office, acting for and on behalf of or performing the duties, functions, and authorities attached to the position. Another thing to carry out the inherent authority function is the organ of the equipment, i.e., a person or group of persons who are based on law or 
articles of association that are authorized to represent legal entities (or officials) to engage in legal relationships. (Ibid. 7)

Authority to arrange and manage gives authority to local government to think and determine its way of solving the problem, either by legislation or policy regulation. Discretion is required as a complement to the principle of legality due to congenital disabilities and artificial defects contained in legislation[5]. Bagir Manan mentioned that there are 2 (two) causes of the limitations and weaknesses of written law, namely: a) Law as part of society covers all aspects in life so vast and complex, so it is not possible for all to incarnate in the form of legislation of written invitation, b) Legislation as a written law is generally static which cannot quickly follow the movement of growth, development, and change of society that must be carried out [6]. Limitations of the written law are marked by the existence of any vague norm provisions of open texture norms.

Vage norm is a norm whose understanding cannot be applied precisely, while open norm (open texture) is a norm whose understanding makes character traits over time change [7]. According to Laica, Marzuki discretion is needed to describe and give dynamic so that the administration runs according to the will of the legislator [8]. About discretion, Gilligan states: Discretionary powers exercised by administrative and legal authorities are permissive, and not binding. These powers are granted to these officials by statute or delegation. Discretionary powers do not impose an obligation on a decision-maker to exercise them or to exercise them in a particular manner. Administrative agencies must exercise discretionary powers by legal requirements. Discretionary power must be used reasonably and impartially while avoiding oppression or unnecessary injury[9].

Yang Yang in "Fundamental Research on the Administrative Discretion Standard" states that administrative discretion standards must meet the efficiency of society. First, law enforcement administration requires efficiency in modern economic life. Efficiency refers to the use of social resources to meet the needs and needs of society effectively. Second, the governance process of administrative law enforcement requires the participation of people [10].

Discretion is a variable that influences the responsive legal conception of Philippe Nonet and Philip Szelsnik. "A responsive institution retains the essentials of its integrity firmly while still observing new forces within its environment [11]. To do this, the responsive law reinforces how openness and integrity can support each other despite the conflict between them. Essential justice prioritizes the interests and needs of individuals and communities, through a process of participatory law-making as an instrument of the will of the people. The process of creating a sympathetic character is participatory, inviting the participation of all elements of society, both in terms of individuals and community groups, and must also be inspirational which is derived from the will or the will of the community. In this study, responsive legal theory is used to analyze the use of discretion in local government.

The reason for decentralization is because it provides opportunities for community participation and regional self-reliance and ensures the accuracy of public officials in providing services to the community. In line with the reform process, Indonesia is now moving from centralized towards decentralization governance.

In line with the reform process, Indonesia is now moving towards governance from centralized to decentralization. Along with this, the road to the welfare state format can be done in harmony with the new third way of social democrat. The orientation of the welfare state does not lead to a prominent government but goes through a process of delegating authority and structuring the new relational format between central and local government based on political autonomy at the local level. Here, the delegation of authority, the autonomy 
of commercial financing, and autonomous decision making have a positive influence on the common welfare. In this context, the bureaucracy must also run rationally and impartially. The format of the welfare state is not synonymous with centralized bureaucracy, which slow and inflexible to the changing context of the times [12].

Indonesia has experienced three times of amendment to the Law on Regional Autonomy Law, namely Law Number 22 the Year 1999, Law Number 32 the Year 2004 regarding Regional Government (revision of Law Number 22 the Year 1999), and Law no. 23 of 2014 as a revision of Law Number 32 the Year 2004.

Thus, it allows local governments to implement policies with higher welfare. As long as no rule of law is violated, and as long as there is no use of power at the local level to build rivalry with central power, the local government has a broader space to implement welfare policies.

Decentralization is a means to give authority to regions to be able to initiate in their local government. It gives authority to local governments to organize and manage the interests of local communities that lead to the use of discretion. The discretion of the regional head in the administration of the region is accommodated in the existing legislation, as can be seen in the table below.

Table I. Disclosure rules to regional heads

\begin{tabular}{|c|c|c|c|}
\hline No & laws & Article & Contain \\
\hline 1 & $\begin{array}{l}\text { Law } \\
\text { Numb } \\
\text { er } 23 \\
\text { the } \\
\text { Year } \\
2014\end{array}$ & $\begin{array}{l}\text { Item } 9 \text { is a } \\
\text { general } \\
\text { explanatio } \\
\mathrm{n}\end{array}$ & $\begin{array}{l}\text { The protection of } \\
\text { innovative activities } \\
\text { undertaken by the state } \\
\text { civil apparatus in the } \\
\text { Region in advancing its } \\
\text { Region. It needs an effort } \\
\text { to spur regional creativity } \\
\text { to improve the } \\
\text { competitiveness of the } \\
\text { Region. Therefore, there } \\
\text { needs to be an objective } \\
\text { criterion that can be used } \\
\text { as a guide for local } \\
\text { officials to conduct } \\
\text { innovative activities. }\end{array}$ \\
\hline 2 & $\begin{array}{l}\text { Law } \\
\text { Numb } \\
\text { er } 23 \\
\text { the } \\
\text { Year } \\
2014\end{array}$ & $\begin{array}{l}\text { Article } 17 \\
\text { paragraph } \\
\text { (1) }\end{array}$ & $\begin{array}{l}\text { The regions shall have the } \\
\text { right to enact Regional } \\
\text { policies to administer } \\
\text { Government Affairs which } \\
\text { are under the jurisdiction } \\
\text { of the Regions }\end{array}$ \\
\hline 3 & & $\begin{array}{l}\text { Article } 22 \\
\text { paragraph } \\
(1)\end{array}$ & $\begin{array}{l}\text { The regions shall have the } \\
\text { right to enact Regional } \\
\text { policies in implementing } \\
\text { Co-Administration Tasks }\end{array}$ \\
\hline 4 & & $\begin{array}{l}\text { Article } 65 \\
\text { paragraph } \\
\text { (2) } \mathrm{c}, \mathrm{d}\end{array}$ & $\begin{array}{l}\text { c. To establish the } \\
\text { Regional Head's Decree } \\
\text { and Decree } \\
\text { d. The Regional Head }\end{array}$ \\
\hline
\end{tabular}




\begin{tabular}{|c|c|c|c|}
\hline & & & $\begin{array}{l}\text { shall be authorized to take } \\
\text { certain actions in urgent } \\
\text { circumstances which are } \\
\text { urgently needed by the } \\
\text { Region and the community }\end{array}$ \\
\hline 5 & & $\begin{array}{l}\text { Article } \\
\text { 258paragra } \\
\text { ph (1) }\end{array}$ & $\begin{array}{l}\text { The region carries out } \\
\text { development for the } \\
\text { improvement and equitable } \\
\text { distribution of people's } \\
\text { income, employment } \\
\text { opportunities, business } \\
\text { field, improving access, } \\
\text { and quality of public } \\
\text { services and } \\
\text { competitiveness of the } \\
\text { Region. }\end{array}$ \\
\hline 6 & $\begin{array}{l}\text { Law } \\
\text { Numb } \\
\text { er } 30 \\
\text { the } \\
\text { Year } \\
2014\end{array}$ & $\begin{array}{l}\text { Article } 22 \\
\text { paragraph } \\
\text { (1) }\end{array}$ & $\begin{array}{l}\text { Discretion can only be } \\
\text { done by the Official } \\
\text { Authorized Government }\end{array}$ \\
\hline 7 & & Article 23a & $\begin{array}{l}\text { Discretionary Government } \\
\text { Officials include decision- } \\
\text { making and action under } \\
\text { the provisions of laws and } \\
\text { regulations that provide an } \\
\text { option Decision and } \\
\text { Action }\end{array}$ \\
\hline 9 & & $\begin{array}{l}\text { Article } 22 \\
\text { b }\end{array}$ & $\begin{array}{l}\text { decision-making and } \\
\text { action because of } \\
\text { legislation is not regulated }\end{array}$ \\
\hline 10 & & $\begin{array}{l}\text { Article } 22 \\
\text { c }\end{array}$ & $\begin{array}{l}\text { Decision-making and } \\
\text { Action due to incomplete } \\
\text { or unclear legislation }\end{array}$ \\
\hline 11 & & $\begin{array}{l}\text { Article } 22 \\
\text { d }\end{array}$ & $\begin{array}{l}\text { Decision-making and } \\
\text { Action due to government } \\
\text { stagnation for broader } \\
\text { interests. }\end{array}$ \\
\hline
\end{tabular}

However, existing legislation also imposes many restrictions on the implementation of local government discretion. In practice, however, it should refer to setting Norms, Standards, Procedures, and Criteria (NSPC) made by the Central Government. The Central Government is authorized to a. stipulate norms, standards, procedures, and criteria in the context of the implementation of Government Affairs; and b. Carry out guidance and supervision on the implementation of Government Affairs, which is the authority. The results of the implementation in 5 research areas indicate that: in order to support the implementation of regional autonomy, all matters require NSPC, causing the execution of affairs to be inefficient. 
The inefficiency occurs because the affairs are too specific to set the standard reference. Another region with other regions is not at the same level of progress. Local government affairs in public services often require an immediate resolution with the application of discretion NSPC which will be a problematic constraint that may result in inefficient or inaccurate decisions The weakness of local affairs which must be guided by NSPC if NSPC has not been established is it creates a lack of clarity in the management of affairs, institutions, finances, and services. These affairs are implemented by the local government and usually in the implementation using local budgets.

The results of research on 5 areas using discretion to solve existing problems in Bantul Regency, Yogyakarta City, Solo City, Bantaeng and Temanggung Regency indicate that if Head of the region is able to comprehend law as responsive law containing Pancasila values (esp) embodied with the participation of citizens then the legal products and actions resulting from the application of discretion will achieve the goal. It is proven in the application of discretion in Bantul Regency in the earthquake disaster prevention (2006), Yogyakarta City in cold lava handling (2010), Solo City in the handling of street hawkers (2008-2011), Bantaeng Regency in overcoming drought, flood and health problems (2009 -2014). Meanwhile, in Temanggung Regency, the use of discretion failed to achieve the goal because it is unable to interpret the responsive law and does not involve community participation.

The rules that limit the use of the discretion to the Head of Region by the Central Government are Article 17 paragraph (2) of Law No.23 of 2014 and Law Number 30 on Government Administration, in which Discretion is arranged in great detail, resulting in the discretion of losing its "spirit", as the essential thing indiscretion is that officials have the freedom of the way in which the power is exercised to achieve the goal rather than just carrying out detailed rules.

\section{Conclusion}

Application of discretion in the implementation of local government is necessary. Submission of broad authority to the region should be balanced with initiative, creativity, and innovation capabilities for the development of each region. However, Law No. 23 of 2014 on Regional Government limits the application of discretion. The existence of the obligations of local government to use NPSK (Norms, Procedures, Systems, and Criteria) established by the Central Government will reduce the use of discretion in the region. Law Number 30 the Year 2014 on Government Administration also imposes restrictions on the application of discretion. Discretion is arranged in great detail, with some provisions restricting the application of discretion, including to officials in local government.

From the restriction limitations, the application of discretion to the Regional Government has not fully characterized the responsive law. Restrictions with detailed rules are the characteristic of autonomous law.

\section{References}

[1] E. Nurbaningsih, Actualization of Arrangement of Authority to Regulate Regional Affairs In Regional Regulation. Yogyakarta: Universitas Gajah Mada, 2011.

[2] S. K. Goesniadhie, "Analysis of Realizing Decentralization and Regional Autonomy," J Law Maksigama, vol. XXXIII, no. 1, p. 2, 2009.

[3] A. Dwiyanto and et al., Reform of Governance and Regional Autonomy. Yogyakarta: Center for Population and Policy Studies of Gadjah Mada University, 2003. 
[4] R. Tjandra, PTUN Encourages the Realization of a Clean and Authoritative Government. Yogyakarta: Atmajaya University of Yogyakarta, 2009.

[5] R. Ridwan, Government Discretion and Responsibility. Yogyakarta: FH UII Press, 2014.

[6] A. Nirwanto, "Direction of Corruption Eradication Forward-Post Law of Government Administration," in National Seminar of IKAHI Anniversary, March 26, 2015, 2015.

[7] S. Sidharta, JJH Briggink Reflection on Law. Bandung: Citra Aditya Bakti, 1998.

[8] L. Marzuki, "Questioning the Use of Discretion in the Administration of the Government," in National Seminar of IKAHI Anniversary, March 26, 2015, 2015.

[9] D. J. Galligan, Discretionary Power. New York: Oxford University Press, 1990.

[10] Y. Yang, "No Title," Beijing Law Rev., vol. 3, pp. 128-32, 2012.

[11] P. N. P. Zelnick, Responsive Law. Bandung: Nusamedia, 2007.

[12] H. T. Simarmata and et al., State of Welfare and Globalization. Jakarta: PSIK \& The Asia Foundation, 2007. 